\title{
Autocorrection - how to measure the skills acquired during physical therapy sessions
}

\author{
HR Weiss, ${ }^{*}$ S Seibel \\ From 8th International Conference on Conservative Management of Spinal Deformities and SOSORT 2011 \\ Annual Meeting \\ Barcelona, Spain. 19-21 May 2011
}

\section{Background}

It is common sense that physiotherapy in the treatment of scoliosis patients should improve the skills for active self-correction of the individual patient [1,2]. Although the autocorrection (AC) patients can achieve when they use certain high correction exercises obviously can be observed, there is no tool to enable the measuremet of this patient skill. Aim of this study was to test whether $\mathrm{AC}$ can be measured with the help of the Scoliometer (ATR) [3].

\section{Materials and methods}

9 Patients with Idiopathic Scoliosis (2 males and 7 females) (IS) with an average Cobb angle of $46^{\circ}\left(29-64^{\circ}\right)$ and with an average age of $14(11-18)$ years underwent a five days course of Scoliosis Short-Term Rehabilitation $($ SSTR). ATR (Angle of Trunk Rotation $=$ Scoliometer) measurements were taken before and after the treatment. Additionally, the ability to correct themselves (AC) was measured after four days of treatment.

\section{Results}

The ATR was reduced significantly from $10.3^{\circ}$ to $8.2^{\circ}(\mathrm{p}<$ $0,001)$ after treatment in the nine patients with scoliosis. The ability to correct themselves (AC) as measured with the help of the Scoliometer (ATR 8.2 / ATR 5.7 autocorrected without additional help by the therapist) was 1,45 and the difference between ATR 8.2 / ATR autocorrected $5.7^{\circ}$ was significant as well $(p=0,0035)$.

\section{Conclusions}

Measurement of autocorrection is possible. The relation ATR / ATR autocorr. will usually be 1 (no autocorrection possible) at the start of the very first specific

Orthopedic Rehabilitation Services, Gensingen, Germany treatment and may increase when the patient gains the necessary exercising skills.

Published: 27 January 2012

\section{References}

1. Weiss HR: Befundgerechte Physiotherapie bei Skoliose. Pflaum, Munich; 3 2011.

2. Weiss $H R$, Klein $R$ : Improving excellence in scoliosis rehabilitation: a controlled study of matched pairs. Pediatr Rehabil 2006, 9:3.

3. Weiss HR, Seibel S: Scoliosis short-term rehabilitation (SSTR) - a pilot investigation. The Internet Journal of Rehabilitation 2010, 1:1 [http://http:/ / www.ispub.com/ journal/ the_internet_journal_of_rehabilitat ion/ volume_1_number_1_73/ article/ scoliosis-short-term-rehabilitation -sstr-apilot-investigation.html].

doi:10.1186/1748-7161-7-S1-P20

Cite this article as: Weiss and Seibel: Autocorrection - how to measure the skills acquired during physical therapy sessions. Scoliosis 2012 7(Suppl 1):P20.
Submit your next manuscript to BioMed Central and take full advantage of:

- Convenient online submission

- Thorough peer review

- No space constraints or color figure charges

- Immediate publication on acceptance

- Inclusion in PubMed, CAS, Scopus and Google Scholar

- Research which is freely available for redistribution
() Biomed Central

\section{() Biomed Central}

